\title{
Traditional treatment of human and animal salmonelloses in Southern Benin: Knowledge of farmers and traditherapists
}

T. V. Dougnon ${ }^{1,2}$, E. Déguénon ${ }^{1,3}$, L. Fah ${ }^{1}$, B. Lègba ${ }^{3}$, Y. M. G. Hounmanou ${ }^{1}$, J. Agbankpè ${ }^{1}$, A. Amadou ${ }^{1}, H$. Koudokpon ${ }^{1}$ K. Fabiyi ${ }^{1}$, A. Aniambossou ${ }^{1}$, P. Assogba ${ }^{1}$, E. Hounsa ${ }^{1}$, M. de Souza ${ }^{1}$, F. Avlessi ${ }^{4}$, T. J. Dougnon ${ }^{1}$, F. Gbaguidi ${ }^{5}$, M. Boko ${ }^{2}$ H. S. Bankolé ${ }^{1}$ and L. Baba-Moussa ${ }^{3}$

1. Research Laboratory in Applied Biology, Polytechnic School of Abomey-Calavi, University of Abomey-Calavi,

01 PO Box 2009 Cotonou, Benin; 2. Laboratory of Hygiene, Sanitation, Toxicology and Environmental Health, Interfacultary Center of Training and Research in Environment for Sustainable Development, University of Abomey-Calavi, 01 PO Box 1463 Cotonou, Benin; 3. Laboratory of Biology and Molecular Typing in Microbiology, Faculty of Sciences and Techniques, University of Abomey-Calavi, 05 PO Box 1604 Cotonou, Benin; 4. Laboratory of Training and Research in Applied Chemistry, Polytechnic School of Abomey-Calavi, University of Abomey-Calavi, 01 PO Box

2009 Cotonou, Benin; 5. National Laboratory of Pharmacognosy, Beninese Center for Scientific and Technical Research, 01 PO Box 06 Oganla, Porto-Novo, Benin.

Corresponding author: T. V. Dougnon, e-mail: victorien88@hotmail.com,

Co-authors: ED: mixesther2009@yahoo.fr, LF: fahlori_2006@yahoo.fr, BL: legba.boris5@gmail.com, YMGH: gilmahu@yahoo.fr, JA: agbankpejerrold@yahoo.fr, AA: afoussaa82@gmail.com,

HK: charleshornel@yahoo.fr, KF: kafayathfabiyi@yahoo.fr, A Aniambossou: anialidah@outlook.fr,

PA: esseconstant.assogba@gmail.com,EH: edihouns@gmail.com, MS: murielraissa@gmail.com, FA: avlessif@yahoo.fr, TJD: dougnonj@yahoo.fr, FG: ahokannou@yahoo.fr, MB: bokomichel@gmail.com, HSB: bahosour@yahoo.fr, LB: laminesaid@yahoo.fr

Received: 12-02-2017, Accepted: 12-05-2017, Published online: 03-06-2017

doi: 10.14202/vetworld.2017.580-592 How to cite this article: Dougnon TV, Déguénon $E$, Fah L, Lègba $B$, Hounmanou YMG, Agbankpè J, Amadou A, Koudokpon H, Fabiyi K, Aniambossou A, Assogba P, Hounsa E, de Souza M, Avlessi F, Dougnon TJ, Gbaguidi F, Boko M, Bankolé HS, Baba-Moussa L (2017) Traditional treatment of human and animal salmonelloses in Southern Benin: Knowledge of farmers and traditherapists, Veterinary World, 10(6): 580-592.

\begin{abstract}
Aim: This study aimed to report medicinal plants that are likely to be used in the control of salmonellosis.

Materials and Methods: A cross-sectional study was conducted in Southern Benin. Semi-structured questionnaires were administered to 150 farmers and 100 traditional therapists in seven high municipalities. This step helped to collect plants that are used in the treatment of animal salmonellosis and typhoid fever in human.

Results: The results revealed a low level of use of medicinal plants among breeders who prefer antibiotics such as oxytetracycline (53.55\%), tylosine + sulfadimerazine (15.30\%), and alphaceryl (19.13\%). However, plants such as Moringa oleifera (leaves), Carica papaya (leaves and seeds), and Vernonia amygdalina (leaves) were mostly used by some farmers. From traditional therapists, 57 plant species of 32 families were identified as typhoid fever cures; among which Leguminosae, Asteraceae, and Euphorbiaceae were predominant. Persea americana (22.72\%), V. amygdalina (7.57\%), and Corchorus olitorius $(7.57 \%)$ were the most cited by traditherapists for the treatment of typhoid fever in human.
\end{abstract}

Conclusion: This study provides a database for further studies on the in vitro and in vivo efficacy of Benin plant species on Salmonella spp. These evaluations will guarantee the availability of new therapeutic solutions for populations.

Keywords: farmers, medicinal plants, salmonellosis, Southern Benin, traditherapists.

\section{Introduction}

Animal husbandry is one of the main activities undertaken in developing countries for livelihood. It contributes greatly to the world economy. However, the performances of the livestock sector can be hindered by a number of factors including infectious diseases such as salmonelloses [1]. In developing countries such as Benin, enteric infections and foodborne diseases constitute a major preoccupation of public health because of their incidence and severity.

Copyright: Dougnon, et al. Open Access. This article is distributed under the terms of the Creative Commons Attribution 4.0 International License (http://creativecommons.org/licenses/ by/4.0/), which permits unrestricted use, distribution, and reproduction in any medium, provided you give appropriate credit to the original author(s) and the source, provide a link to the Creative Commons license, and indicate if changes were made. The Creative Commons Public Domain Dedication waiver (http:// creativecommons.org/publicdomain/zero/1.0/) applies to the data made available in this article, unless otherwise stated.
Foodborne diseases cause more than 17 million deaths per year worldwide, and more than half occurs in Africa [2]. Animals have been reported to be the main sources of transmission of Salmonella spp. to human. The poor hygiene level of the livestock systems in West Africa can encourage the introduction of pathogenic germs in farms [1]. Serotypes of Salmonella that cause minor salmonelloses are part of the important pathogenic foodborne bacteria, with a large range of hosts, including animals and human. Salmonella Enterica is one of the main causative agents of foodborne diseases (11\%), hospitalization (35\%), and death (28\%) in the United States of America [3]. Moreover, most strains of Salmonella species, like S. Typhimurium, were proven to be resistant to many antibiotics [4]. It is universally admitted that the emergence of antimicrobial resistance, in particular, multidrug resistance (MDR) of Salmonella strains to ampicillin, 
chloramphenicol and cotrimoxazole, has complicated the treatment and management of salmonellosis [5]. In spite of the increasing negative impact of salmonelloses on public health, limited information is available regarding the prevalence, the antibiotics susceptibility and the mechanism of MDR of these strains in Benin. Actually, the control of the evolution of drug-resistant strains of Salmonella at animals' level is a key to preserving the transmission toward humans who are big consumers of meat.

Typhoid fever, a potentially life-threatening gastrointestinal infection, is caused by a non-spore bearing bacilli called Salmonella Enterica serovar Typhi (S. Typhi) [6]. This bacterium is transmitted by faecal-oral route with the organism gaining entry into the body through the intestinal mucosa [7]. Advances in public health strategies, technology, and hygiene have led to the eradication of typhoid fever from the developed world, but since the 1800s, typhoid fever has remained an endemic disease in many developing countries $[8,9]$.

This is worrying because of the high morbidity and mortality associated with typhoid fever [10], particularly in children under 5 years old $[11,12]$ and the emergence of MDR S. Typhi [9,13-15]. The sources of infection vary but the most common mode of transmission is by ingesting an infective dose of S. Typhi through contaminated food or water. The true global disease burden of typhoid fever is difficult to be estimated as few established surveillance systems on typhoid fever exist in developing countries [9].

For example, in Africa, the overall burden of typhoid fever remains largely unknown, mainly because facilities capable of performing the blood culture tests essential for diagnosis are absent from many regions [16].

Untreated typhoid fever can lead to gruelling complications such as gastrointestinal hemorrhage, hepatomegaly, anorexia, diarrhea, toxicity, encephalopathy, myocarditis, and disseminated intravascular coagulation [17]. For decades, antibiotics such as chloramphenicol, ampicillin, and cotrimoxazole were the mainstay of typhoid treatment [18]. However, the widespread emergence of MDR S. Typhi necessitated the search for other therapeutic alternatives such as the fluoroquinolones, third generation cephalosporins, and azalides [19]. Fluoroquinolones are, however, restricted from routine use in children and quinolone-resistant $S$. Typhi strains have been documented [20-22]. Ceftriaxone is highly effective against $S$. Typhi but parenteral administration limits its usage [20]. Azithromycin is however very effective against $S$. Typhi [23]. These drugs are very expensive and less affordable to a majority of individuals in developing countries such as Benin, hence a greater proportion of the population resort to the use of herbal medicines. It is estimated that about $80 \%$ of the world's population rely on traditional medicine, particularly herbal medicine for primary health care $[2,24,25]$.

Benin is a land of immense biodiversity and a hub of very potent and efficacious medicinal plants which are involved either in the holistic treatment of diseases or the alleviation of symptoms. An impressive number of plants have been used traditionally in the treatment of typhoid fever in Africa since immemorial times [26].

This survey was therefore carried out to investigate plants used by breeders to treat salmonelloses in animals and those used by traditional healers to treat typhoid fever in human. The final goal is the development of new, cost-effective and easily accessible medicines against typhoid fever in Benin but also to overcome MDR of Salmonella spp.

\section{Materials and Methods}

\section{Ethical approval}

The study was conducted among Beninese individuals. Each target was maintained in relation to the objectives of the study and a written consent form was signed. These targets were free to participate or not to participate in the study.

\section{Study area and materials}

The study was conducted in Southern Benin located between $6^{\circ} 25 \mathrm{~N}$ and $7^{\circ} 30^{\prime} \mathrm{N}$, covering a surface of $17109 \mathrm{~km}^{2}$. The climate is of sub-equatorial type, characterized by a bimodal rainfall regime with two rainy seasons alternated by two dry seasons. The average annual temperature is $28^{\circ} \mathrm{C}$, and the air humidity varies between $69 \%$ and $97 \%$ [27]. The most dominant soils are ferralitic soils on clayey sediments, hydromorphic soils in the valleys, shallows and alluvial plains, vertisoils in the depression of Lama, and tropical eutrophic brown soils [28]. Phytogeographically, Southern Benin is subdivided into four districts: Coastal, Pobè, Ouémé Valley, and Plateau [29]. It belongs to the Guineo-Congolese zone that comprises mosaic humid and dense islets of forests, savannahs, prairies, mangrove swamps, and fallows. The present ethnopharmacological survey was conducted in 7 Municipals of Southern Benin, namely, Porto-Novo, Dangbo, Cotonou, AbomeyCalavi, Sèmè, and Adjarra and Ouidah (Table-1). These municipals were chosen based on the presence of many traditherapists and farmers revealed by the previous studies [30]. The materials used were questionnaires for interviews, digital camera, voice recorder, plastic bags, sticky tape, and marker pens.

Table-1: Townships covered by the survey.

\begin{tabular}{ll}
\hline $\begin{array}{l}\text { Nationals departments } \\
\text { of Southern Benin }\end{array}$ & Investigated areas \\
\hline Atlantique & Abomey-Calavi \\
Littoral & Cotonou, Ouidah \\
Plateau & Sèmè \\
Ouémé & Porto-Novo, Dangbo, Adjarra \\
\hline
\end{tabular}




\section{Sampling}

The study enrolled 50 pig farmers, 50 chicken farmers, and 50 cattle keepers randomly selected from the list of farmers available in Southern Benin. These farmers were interviewed within a semi-structured questionnaire. The selection of the three types of animals (pigs, chicken and cattle) was justified by their predominance in the food habit of the concerned study population. For traditherapists, a total of 100 people were enrolled in the study. This was based on stratified random sampling.

\section{Sampling procedure}

One-on-one interviews were conducted using semi-structured questionnaires for farmers and traditional healers.

\section{Interview with farmers}

A questionnaire was designed and administered to probe information on botanical, ethnobotanical, and ethnoveterinary potentials of the traditional recipes used against salmonelloses in animals. Further information collected based on the questionnaire was the profile of the interviewed farmer, the local names of the plants used to treat or to prevent salmonellosis and the recipes related to these plants.

\section{Interviews with traditherapists}

A questionnaire was designed to collect information related to botanical, ethnobotanical, and ethnopharmacological potentials of the recipes used against typhoid fever. The investigation starts by a preparatory phase during which meetings were organized with the traditional healers. The collected information was basically about the profile of the investigated therapist and the ethnopharmacological data of the plants used to treat or to prevent typhoid fever.

For the two surveys, we were focused on the local names and the parts of plants that are used, as well as the therapeutic indications, all possible recipes, the mode of administration, and the potential side effects.

\section{Identification of plant species}

The plants mentioned in the local languages Fon, Goun and Mina were compared with other references such as Contribution to ethnobotanical and floristic studies in Populary Republic of Benin [31]; Flora of Benin: Names of plants in Beninese National languages [32] and the analytic flora of Benin [27].

\section{Literature review}

A scientific literature review was performed on plants potentially active in the treatment of salmonellosis to make an inventory of the already existing data on the plants revealed by this study. It was also meant to record further plants reported in the literature for their anti-Salmonella properties but not mentioned in the present study. This was a complete desk study searching through online scientific databases, specialized works, and publications. The number of references documented, the relevance, and the repetition of the information was considered. A large number of references on a plant frequently cited from different countries demonstrate a certain medicinal interest of that particular plant. The information was judged significant when reported in several references.

\section{Statistical analyses}

The collected data were encoded and recorded in an Excel database. Descriptive statistics were performed using SPSS 20.

\section{Results}

Endogenous knowledge of farmers related to plants used in the treatment of animal salmonellosis

\section{Sociocultural characteristics of farmers included in} the survey

A total of 150 farmers were interviewed including $96 \%$ male and $4 \%$ female farmers unequally distributed in the townships of Abomey-Calavi (76\%), Cotonou (2,67\%), Ouidah (6,67\%), Porto-Novo $(6,67 \%)$, Sèmè-Kpodji (4,67\%), Dangbo (1,33\%), and Adjarra (2\%). The highest number of investigated farmers was found in Abomey-Calavi (76\%) whereas Dangbo harbors the lowest number of enrolled farmers $(1.3 \%)$.

Livestock practices are one of the dominant activities in Southern Benin. The study showed that more men are involved in these activities than women. Respondents belong to diverse ethnic groups mainly Fon and Goun but some were Mina, Yoruba, and Bariba.

Animal production in the study area is a lucrative activity that commonly uses domestic workforce but sometimes coupled with salaried employers.

Most animals were raised in confinement except cattle that were kept on free grazing but under the control of Peulh herders who are mostly illiterate and inherited the animals from their parents.

Several wards of Abomey-Calavi, Cotonou, Ouidah, Porto-Novo, Sèmè-Kpodji, Dangbo, and Adjarra were visited to meet farmers who participated in this study. Abomey-Calavi had the highest proportion of farmers. The study also revealed that the investigated farmers have other activities and were classified into four categories: Exclusive animal producers (88\%) followed by $5.33 \%$ of crop producers and $4 \%$ traders then $2.67 \%$ of veterinarians.

The study revealed that $22.67 \%$ of the farmers have high-level education, $48.67 \%$ have secondary education, $16.67 \%$ have primary education, and $12.00 \%$ were illiterate. About $55.55 \%$ of farmers who went to University had professional training on animal husbandry, and $33 \%$ of all respondents had an informal training for animal farming while $6.66 \%$ became breeders just by inheritance. The youngest breeder was 23 years and the oldest 62 years old.

Table-2 shows the distribution of farmers based on their age, size of household, professional experience, and herd size. 
Knowledge of breeders on plants used in the treatment of animal salmonellosis

Out of the 150 farmers enrolled in the study, only $36 \%$ mentioned plants that are useful as antiSalmonella. In majority of cases, this knowledge was acquired from another farmer. They do not use the plants in the treatment of their animals because there is no evidence of effectiveness of these plants.

\section{Plants used by selected farmers against Salmonellosis}

As displayed in Table-3 [33-40], Moringa oleifera (leaves), Carica papaya (leaves and seeds), and Vernonia amygdalina (leaves) were the most cited plants used by farmers to treat salmonellosis in slaughter animals. The same table also shows that these plants are used either dried or macerated. They are given to the animals orally in feed or water (Table-3).

\section{Antibiotics used in animals}

All the investigated farmers use synthetic antibiotics. The most cited antibiotics are classified in Table-4. These antibiotics are used as preventive and curative drugs. However, antibiotics are systematically used when animals are sick. Oxytetracycline was the most cited antibiotic (53.55\%), followed by tylosine + sulfadimerazine and alphaceryl with citation frequencies of $15.30 \%$ and $19.13 \%$, respectively.

Endogenous knowledge of traditherapists related to plants used for the treatment of human salmonellosis

A total of 100 traditherapists were enrolled including 97\% men and 3\% women, from 7 municipalities of Southern Benin: Abomey-Calavi, Cotonou, Ouidah, Porto-Novo, Sèmè-Kpodji, Dangbo, and Adjarra. The majority of these respondents were found in Porto-Novo (18\%), while Cotonou had the lowest number of traditherapists (10\%) (Table-5).

About $78 \%$ of the traditherapists were illiterate. The remaining had primary, secondary, or university education. They belong to 4 ethnic groups of Benin: Fon $(42 \%)$, Goun $(32 \%)$, Wémè $(15 \%)$, and Yoruba
$(11 \%)$. Most of them were Fon $(42 \%)$ whereas the minority was Yoruba.

\section{Knowledge of traditherapists about plants that serve as anti-Salmonella in human}

The most respondents were not familiar with the word "Salmonellosis." Symptoms of diarrheal infections and typhoid fever were therefore used to describe salmonelloses. At least one recipe was recorded per traditherapist. The majority of them hesitated to provide the requested information.

The listed recipes contain 57 plant species of 32 families of which the most represented ones were Asteraceae, Leguminosae, and Euphorbiaceae (Table-6). The most cited species in the recipes were: Persea americana (22.72\%), Vernonia amygdalina (7.57\%), Corchorus olitorius (7.57\%) (Table-7). Plants mentioned in the present survey are used either alone or in association with other plants. However, some recipes contain non-plant materials such as alcohol, palm oil, akassa (maize dough), and cow milk. The most used plant organs are the leaves, but also the roots, the bark or the whole plant. Most recipes are prepared as decoctions, but some are macerated in alcohol or water. All recipes are administered orally.

Literature data on the cited plants and their anti-Salmonella properties

Some of the recorded plants were previously reported in the literature with their chemical composition and biological activities (Table-7) [41-46]. The absence of studies on pharmacological data of these plants is an important selection criterion for the identification of original chemical structures which are not yet described.

The literature reviews also revealed 38 medicinal plant species of which some are used traditionally to treat salmonelloses and typhoid fever. Some of these plants have been pharmacologically studied, and their anti-Salmonella properties already reported (Table-8) [47-57].

Table-2: Distribution of farmers based on their age, size of household, professional experience and herd size.

\begin{tabular}{lcccc}
\hline Variable & Maximum & Minimum & Mean & Standard error \\
\hline Age & 62 & 20 & 37.59 & 0.89 \\
Household size & 12 & 2 & 4.49 & 0.16 \\
Professional experience & 27 & 1 & 7.98 & 0.52 \\
Herd size & 4500 & 10 & 520.01 & 65.78 \\
\hline
\end{tabular}

Table-3: Diversity of plants species used as anti-Salmonella in animals.

\begin{tabular}{|c|c|c|c|c|c|c|}
\hline Scientific name & $\begin{array}{l}\text { Vernacular } \\
\text { name (Fongbe) }\end{array}$ & Used part & $\begin{array}{l}\text { Frequency } \\
\text { of citation }\end{array}$ & $\begin{array}{l}\text { Mode of } \\
\text { preparation }\end{array}$ & $\begin{array}{l}\text { Mode of } \\
\text { administration }\end{array}$ & $\begin{array}{l}\text { Citation in } \\
\text { literature }\end{array}$ \\
\hline Moringa oleifera & Kpatiman wini wini & Leaves & 30 & Dried & Oral in feed & {$[33,34]$} \\
\hline Ocimum gratissimum & Tchayo & Leaves & 04 & Macerated & Oral in water & [35] \\
\hline Carica papaya & Kpin & Leaves and seeds & 14 & Dried & Oral in feed & {$[36,37]$} \\
\hline Cajanus cajan & Klouékoun & Leaves & 4 & Dried & Oral in feed & [38] \\
\hline Vernonia amygdalina & Amanvivè & Leaves & 8 & Macerated & Oral in water & {$[39,40]$} \\
\hline Manihot esculenta & Fingnin man & Leaves & 4 & Macerated & Oral in water & [37] \\
\hline
\end{tabular}


Table-4: Antibiotics used by farmers for the treatment of their animals.

\begin{tabular}{lcc}
\hline Antibiotics & $\begin{array}{c}\text { Number of } \\
\text { citations }\end{array}$ & Proportion \\
\hline Oxytetracycline & 98 & 53.55 \\
Tylosine+sulfadimerazine & 28 & 15.30 \\
Alphaceryl & 35 & 19.13 \\
Flumec & 2 & 1.09 \\
Tetracolivit & 8 & 4.37 \\
Penistrepto & 2 & 1.09 \\
Azemite & 2 & 1.09 \\
Colideto & 2 & 1.09 \\
Biocalin & 2 & 1.09 \\
Amprolium & 2 & 1.09 \\
Alphamet & 2 & 1.09 \\
Total & 183 & \\
\hline
\end{tabular}

Table-5: Distribution of respondents by townships.

\begin{tabular}{lcc}
\hline Townships & Number & Proportion (\%) \\
\hline Abomey-Calavi & 13 & 13.00 \\
Cotonou & 10 & 10.00 \\
Ouidah & 15 & 15.00 \\
Porto-Novo & 18 & 18.00 \\
Seme-Kpodji & 13 & 13.00 \\
Dangbo & 15 & 15.00 \\
Adjara & 16 & 16.00 \\
Total & 100 & 100.00 \\
\hline
\end{tabular}

Table-6: Botanical families represented in the medicinal plants cited in the treatment of salmonellosis.

\begin{tabular}{|c|c|}
\hline Botanical family & Proportions \\
\hline Lauraceae & 1.75 \\
\hline Annonaceae & 1.75 \\
\hline Apocynaceae & 5.26 \\
\hline Arecaceae & 5.26 \\
\hline Asteraceae & 7.02 \\
\hline Bignoniaceae & 3.51 \\
\hline Bromeliaceae & 1.75 \\
\hline Capparidaceae & 1.75 \\
\hline Caricaceae & 1.75 \\
\hline Clusiaceae & 1.75 \\
\hline Combretaceae & 1.75 \\
\hline Connaraceae & 3.51 \\
\hline Cucurbitaceae & 3.51 \\
\hline Dracaenaceae & 1.75 \\
\hline Euphorbiaceae & 7.02 \\
\hline Fabaceae & 5.26 \\
\hline Lamiaceae & 5.26 \\
\hline Leguminosae-Caesalpinioideae & 5.26 \\
\hline Leguminosae-Mimosoideae & 1.75 \\
\hline Leguminosae-Papilionoideae & 3.51 \\
\hline Liliaceae & 1.75 \\
\hline Meliaceae & 1.75 \\
\hline Moraceae & 1.75 \\
\hline Moringaceae & 1.75 \\
\hline Myrtaceae & 3.51 \\
\hline Papaveraceae & 1.75 \\
\hline Phyllanthaceae & 1.75 \\
\hline Piperaceae & 1.75 \\
\hline Poaceae & 3.51 \\
\hline Rutaceae & 1.75 \\
\hline Salicaceae & 1.75 \\
\hline Solanaceae & 1.75 \\
\hline Sterculiaceae & 3.51 \\
\hline Malvaceae & 175 \\
\hline Total & 100 \\
\hline
\end{tabular}

\section{Discussion}

The objective of this study was to establish a record of medicinal plants that are used in the treatment of human and animal salmonellosis. This was based on the knowledge of farmers and traditional healers. These two strategic targets were chosen to make the survey more conclusive from human and animal health perspectives. The two investigations reported 63 plant species used in the treatment of salmonelloses in Southern Benin comprising 6 from farmers and 57 from traditherapists. They represent $2.24 \%$ of the total flora of the country that harbors 2807 medicinal plant species [27]. This specific abundance for salmonellosis is higher than those reported by Dassou [58] in the country; and lower as compared to the results of Adomou [44], Fah et al. [59], Dassou et al. [60].

The low level is attributable to the fact that this study was limited to plants used in the treatment of salmonelloses and can also be due to differences in the geographical areas where these studies were conducted. Furthermore, this study demonstrated that more men are involved in animal production than women in the study population. This is because the activity requires a lot of financial inputs, time but also a lot of physical effort. It can also be due to the fact that women prefer commercial activities in the study area. These results are comparable to those of Sacramento [61] who reported similar results among grasscutters keepers. Farmers of the study area do not use herbal medicines for the treatment of their animals mainly the poultry keepers for many reasons: To avoid messing up the prophylaxis, avoid the death of animals the drop of laying rate in layers because they have limited information about the posology.

They, therefore, prefer using synthetic antibiotics. Better results were reported by Dassou et al. [60] who recorded 241 medicinal plant species used in the treatment of 45 animal diseases and symptoms which include $0.90 \%$ of plants against salmonelloses. Nevertheless, most of the plants listed in that study are used against intestinal worms; as found by Ogni et al. [62] from farmers. Moreover, this study revealed that most traditherapists are men. This makes sense because most traditional healers and people involved in herbal medicine in Benin are men. It is rather the sale of the recipes in markets that is reserved for women. In recent times, public interest in natural remedies, mostly herbal medicine, has increased drastically not only in developing countries but also highly industrialized countries [63].

This has increased international trade in herbal medicine tremendously. Self-prescribed herbal remedies are on the ascendancy these days for the treatment of diseases such as headaches, insomnia, fever, intestinal disorders, and typhoid fever [64,65]. 57 medicinal plants of 32 families were recorded from traditional healers, as effective against salmonellosis. Results 
Table-7: Plants used by traditherapists in Southern Benin against human salmonellosis.

\begin{tabular}{|c|c|c|c|c|c|c|c|}
\hline $\mathbf{N}$ & Species & Family & $\begin{array}{l}\text { Vernacular } \\
\text { name }\end{array}$ & $\begin{array}{l}\text { Organs } \\
\text { used }\end{array}$ & $\begin{array}{l}\text { Frequency } \\
\text { of citation }\end{array}$ & $\begin{array}{l}\text { Mode of } \\
\text { utilization } \\
\text { (alone or in } \\
\text { association) }\end{array}$ & $\begin{array}{l}\text { Previous } \\
\text { references }\end{array}$ \\
\hline 1 & Cassytha filiformis L. & Lauraceae & Agbégbékan & Whole plant & $1.51 \%$ & $\begin{array}{l}\text { Alone or in } \\
\text { association }\end{array}$ & \\
\hline 2 & Psidium guayava L. & Myrtaceae & Kinkoun man & $\begin{array}{l}\text { Leaves and } \\
\text { roots }\end{array}$ & 6.06 & In association & \\
\hline 3 & Jatropha gossypifolia & Euphorbiaceae & $\begin{array}{l}\text { Yonkpotin vovo } \\
\text { man }\end{array}$ & Leaves & 3.03 & In association & \\
\hline 4 & Cola nitida & Sterculiaceae & Gba'n dja & Fruits & 1.51 & Alone & \\
\hline 5 & $\begin{array}{l}\text { Vernonia } \\
\text { amygdalina }\end{array}$ & Asteraceae & Aman vivè & Leaves & 7.57 & $\begin{array}{l}\text { Alone or in } \\
\text { association }\end{array}$ & $\begin{array}{c}\text { Eth: }[41] \\
\text { Pharm: [39] }\end{array}$ \\
\hline 6 & $\begin{array}{l}\text { Crateva adansonii } \\
\text { DC. }\end{array}$ & Capparidaceae & Hontonzouzoin & Leaves & 1.51 & $\begin{array}{l}\text { Alone or in } \\
\text { association }\end{array}$ & $\begin{array}{c}\text { Eth: [41] } \\
\text { Pharm: [39] }\end{array}$ \\
\hline 7 & Xylopia aethiopica & Apocynaceae & Kpédjrékoun & Fruits & 4.54 & In association & Pharm: [42] \\
\hline 8 & $\begin{array}{l}\text { Caesalpinia } \\
\text { pulcherrima }\end{array}$ & $\begin{array}{l}\text { Leguminosae- } \\
\text { Caesalpinioideae }\end{array}$ & Orgueil de chine & Whole plant & 4.54 & $\begin{array}{l}\text { Alone or in } \\
\text { association }\end{array}$ & \\
\hline 9 & Annona muricata & Annonaceae & Chap chap man & Leaves & 4.54 & Alone & \\
\hline 10 & Citrus limon & Rutaceae & Cléman & Leaves & 4.54 & In association & \\
\hline 11 & Persea americana & Lauraceae & Avocatier & Leaves & 22.72 & In association & \\
\hline 12 & Cocos nucifera & Arecaceae & Agonkè & Leaves & 1.51 & In association & \\
\hline 13 & Carica papaya & Caricaceae & Papaye fruit & Roots & 1.51 & In association & \\
\hline 14 & Khaya senegalensis & Meliacea & Caicédra & Unripe fruit & 1.51 & In association & \\
\hline 15 & $\begin{array}{l}\text { Acanthospermum } \\
\text { hispidum DC. }\end{array}$ & Asteraceae & Ahanglon & $\begin{array}{l}\text { Whole plant } \\
\text { or bark }\end{array}$ & 3.03 & $\begin{array}{l}\text { Alone or in } \\
\text { association }\end{array}$ & \\
\hline 16 & $\begin{array}{l}\text { Senna } \\
\text { siamea (Lam.) H.S. } \\
\text { Irwin \& Barneby. }\end{array}$ & $\begin{array}{l}\text { Leguminosae- } \\
\text { Caesalpinioideae }\end{array}$ & Kassia & Whole plant & 1.51 & In association & \\
\hline 17 & $\begin{array}{l}\text { Eugenia } \\
\text { Caryophyllata }\end{array}$ & Myrtaceae & Atikin gba do ta & Whole plant & 4.54 & In association & \\
\hline 18 & Allium sativum & Liliaceae & Ail & Fruits & 1.51 & In association & \\
\hline 19 & $\begin{array}{l}\text { Corchorus olitorius } \\
\text { L. }\end{array}$ & Malvaceae & Crincrin & Leaves & 7.57 & In association & \\
\hline 20 & Abrus precatorius L. & Fabaceae & Viviman & Whole plant & 3.03 & In association & \\
\hline 21 & $\begin{array}{l}\text { Croton zambesicus } \\
\text { Muell. }\end{array}$ & Euphorbiaceae & Djélélé & Whole plant & 3.03 & In association & \\
\hline 22 & $\begin{array}{l}\text { Cajanus cajan (L.) } \\
\text { Millsp. }\end{array}$ & Fabaceae & Klouékounman & Leaves & 3.03 & $\begin{array}{l}\text { Alone or in } \\
\text { association }\end{array}$ & \\
\hline 23 & $\begin{array}{l}\text { Kigelia } \\
\text { africana (Lam.) } \\
\text { Benth }\end{array}$ & Bignoniaceae & Gnanblikpo & Leaves & 3.03 & $\begin{array}{l}\text { Alone or in } \\
\text { association }\end{array}$ & \\
\hline 24 & $\begin{array}{l}\text { Momordica charantia } \\
\text { L. }\end{array}$ & Cucurbitaceae & Gninsikin & Leaves & 3.03 & In association & \\
\hline 25 & Garcinia cola Heckel. & Clusiaceae & Ahowé & Fruits & 1.51 & In association & \\
\hline 26 & Cucumis metuliferus & Curcubitaceae & Gbohounon & Fruits & 3.03 & $\begin{array}{l}\text { Alone or in } \\
\text { association }\end{array}$ & \\
\hline 27 & $\begin{array}{l}\text { Piper guineense } \\
\text { Schumach. \& Thonn. }\end{array}$ & Piperaceae & Linlinkoun & Seeds & 1.53 & In association & \\
\hline 28 & Moringa Oléifera & Moringaceae & $\begin{array}{l}\text { Yovo kpatin } \\
\text { ou kpatinma } \\
\text { wini- wini }\end{array}$ & Leaves & 3.03 & Alone & \\
\hline 29 & Newbouldia laevis & Bignoniaceae & Déssréman & Leaves & 4.54 & In association & \\
\hline 30 & $\begin{array}{l}\text { Elaeis guineensis } \\
\text { Jacq. }\end{array}$ & Arecaceae & Déman & Leaves & 1.51 & In association & \\
\hline 31 & $\begin{array}{l}\text { Ocimum } \\
\text { gratissimum L. }\end{array}$ & Lamiaceae & Tchiayo & Leaves & 1.51 & In association & $\begin{array}{c}\text { Eth: }[34,41] \\
\text { Pharm: }[35,39,43]\end{array}$ \\
\hline 32 & Cocos nucifera & Arecaceae & Agonkèssin & $\begin{array}{l}\text { Coconut } \\
\text { water }\end{array}$ & 1.51 & In association & \\
\hline 33 & Catharanthus roseus & Apocynaceae & Bonjourbonsoirdo & Whole plant & 1.51 & In association & \\
\hline 34 & $\begin{array}{l}\text { Haematoxylum } \\
\text { campechianum L. }\end{array}$ & $\begin{array}{l}\text { Leguminosae- } \\
\text { Caesalpinioideae }\end{array}$ & Campècher & Leaves & 1.51 & In association & \\
\hline 35 & Cola millenii & Sterculiaceae & Aloviaton & Leaves & 1.51 & $\begin{array}{l}\text { Alone or in } \\
\text { association }\end{array}$ & \\
\hline 36 & $\begin{array}{l}\text { Cymbopogon } \\
\text { citratus }\end{array}$ & Poaceae & Timan & Leaves & 1.51 & $\begin{array}{l}\text { Alone or in } \\
\text { association }\end{array}$ & \\
\hline 37 & Ananas comosus & Bromeliaceae & Ananas & Fruits & 1.51 & In association & \\
\hline 38 & $\begin{array}{l}\text { Caesalpinia } \\
\text { bonduc (L.) Roxb. }\end{array}$ & $\begin{array}{l}\text { Leguminosae- } \\
\text { Caesalpinioideae }\end{array}$ & Adjikouinman & Leaves & 3.03 & $\begin{array}{l}\text { Alone or in } \\
\text { association }\end{array}$ & \\
\hline
\end{tabular}




\begin{tabular}{|c|c|c|c|c|c|c|c|}
\hline $\mathbf{N}$ & Species & Family & $\begin{array}{l}\text { Vernacular } \\
\text { name }\end{array}$ & $\begin{array}{l}\text { Organs } \\
\text { used }\end{array}$ & $\begin{array}{l}\text { Frequency } \\
\text { of citation }\end{array}$ & $\begin{array}{l}\text { Mode of } \\
\text { utilization } \\
\text { (alone or in } \\
\text { association) }\end{array}$ & $\begin{array}{l}\text { Previous } \\
\text { references }\end{array}$ \\
\hline 39 & Phyllostachys aurea & Poaceae & $\begin{array}{l}\text { Feuille de } \\
\text { roseau (bambou) }\end{array}$ & Leaves & 3.03 & Alone & \\
\hline 40 & Sansevieria liberica & Dracaenaceae & Kpognan & Leaves & 1.51 & Alone & Eth: [44] \\
\hline 41 & Argemone mexicana & Papaveraceae & Houètchégnon & Leaves & 1.51 & Alone & Pharm: [45] \\
\hline 42 & Salix babylonica & Salicaceae & $\begin{array}{l}\text { Saule pleureur } \\
\text { (paratonere) }\end{array}$ & Leaves & 1.51 & Alone & \\
\hline 43 & Ficus exasperata & Moraceae & Akaya & Leaves & 1.51 & In association & \\
\hline 44 & Capsicum frutescens & Solanaceae & danhomé takin & Fruits & 1.51 & In association & \\
\hline 45 & $\begin{array}{l}\text { Agelaea pentagyna } \\
\text { Lam. }\end{array}$ & Connaraceae & Ahanhlazu & $\begin{array}{l}\text { Leaves and } \\
\text { roots }\end{array}$ & 1.51 & In association & \\
\hline 46 & $\begin{array}{l}\text { Rourea } \\
\text { coccinea (Thonn. Ex } \\
\text { Schumach.) Benth }\end{array}$ & Connaraceae & Vikplonba & $\begin{array}{l}\text { Leaves and } \\
\text { roots }\end{array}$ & 1.51 & In association & \\
\hline 47 & $\begin{array}{l}\text { Phyllanthus amarus } \\
\text { Schumach.\&.Thonn. }\end{array}$ & Phyllantaceae & Hlenwé & Leaves & 3.03 & $\begin{array}{l}\text { Alone or in } \\
\text { association }\end{array}$ & \\
\hline 48 & $\begin{array}{l}\text { Hyptis suaveolens } \\
\text { Poit. }\end{array}$ & Lamiaceae & Afio & Leaves & 1.01 & In association & \\
\hline 49 & $\begin{array}{l}\text { Acanthospermum } \\
\text { hispidum DC. }\end{array}$ & Asteraceae & Ahanglon & Leaves & 3.02 & $\begin{array}{l}\text { Alone or in } \\
\text { association }\end{array}$ & \\
\hline 50 & $\begin{array}{l}\text { Bridela ferruginea } \\
\text { Benth. }\end{array}$ & Phyllanthaceae & Housoukokwé & Leaves & 1.01 & In association & \\
\hline 51 & $\begin{array}{l}\text { Combretum } \\
\text { micraanthum }\end{array}$ & Combretaceae & Quiqueliba & Whole plant & 1.51 & $\begin{array}{l}\text { Alone or in } \\
\text { association }\end{array}$ & \\
\hline 52 & $\begin{array}{l}\text { Acacia sieberiana } \\
\text { DC. }\end{array}$ & $\begin{array}{l}\text { Leguminosae- } \\
\text { Mimosoideae }\end{array}$ & Aduwéman & Leaves & 3.03 & In association & \\
\hline 53 & $\begin{array}{l}\text { Acanthospermum } \\
\text { hispidum DC. }\end{array}$ & Asteraceae & Awisagbé & Leaves & 3.03 & In association & \\
\hline 54 & Rauvolfia caffra & Apocynaceae & Lèwé & Roots & 1.51 & Alone & \\
\hline 55 & $\begin{array}{l}\text { Erythrina } \\
\text { senegalensis }\end{array}$ & $\begin{array}{l}\text { Leguminosae- } \\
\text { Papilionoideae }\end{array}$ & Kpacléssi & Leaves & 1.51 & In association & Eth: [46] \\
\hline 56 & Baphia nitida & $\begin{array}{l}\text { Leguminosae- } \\
\text { Papilionoideae }\end{array}$ & Sokakpè & Fruits & 1.51 & In association & \\
\hline
\end{tabular}

Eth=Ethnobotanical reference, Pharm=Pharmacological reference

of this study are in accordance with those of Fadimu et al. [40] who recorded in Nigeria almost the same plant species in their ethnomedicinal survey on plants used in the treatment of typhoid fever. However, the most representative plant families in this survey were the Rutaceae, (then Asteraceae), Leguminosae, and Euphorbiaceae. In this study, $P$. americana, $V$. amygdalina, and $C$. olitorius were the three plant species mostly used by traditional healers in the treatment of salmonelloses.

These results are similar to those reported by Agbankpè et al. [41] who documented that $V$. amygdalina is used like infusion to treat diarrheal infections in Cotonou and Abomey-Calavi (South-Benin), with a frequency relatively higher than the one of this study $(16.80 \%)$.

The valorization of the 63 recorded plant species in this survey requires the research of their efficiency in further studies. A number of these plants have already been tested by different studies. HounzangbéAdoté et al. [36] showed that the seeds of C. papaya play an important role in the elimination of gastrointestinal worms in sheep and goats, by either killing the adult worms or by reducing the fertility of the females. Kermanshai et al. [66] demonstrated that benzyl isothiocyanate present in the seed of papaya is the compound responsible for its antihelminthic activity.

However, tannins and flavonoids could also exhibit this property. According to HounzangbéAdoté et al. [67] and Brunette and Hoste [68], tannins block Haemonchus contortus eggs from hatching, kill its adults and reduce their fertility. The frequent citation of C. papaya by several breeders is an evidence of confusion between salmonellosis and intestinal worms because they present mostly similar symptoms such as diarrhea. The research of antibacterial activities of this plant should be envisaged to verify whether is possesses antimicrobial properties against salmonelloses. Koffuor et al. [69] reported that $V$. amygdalina has strong antibacterial activity against salmonelloses. This is because they contain flavonoids, sesquiterpene lactones, saponins, tannins, alkaloids, and sterols in varying degrees [70-72].

Kpodekon et al. [35] demonstrated excellent antibacterial activities of the essential oil of Ocimum gratissimum on Salmonella, and this activity varies from one species to another. According to Kone [73], the leaves of $M$. oleifera have excellent antimicrobial activities because of their high content in sterols, triterpenes, and phenolic compounds notably tannins 


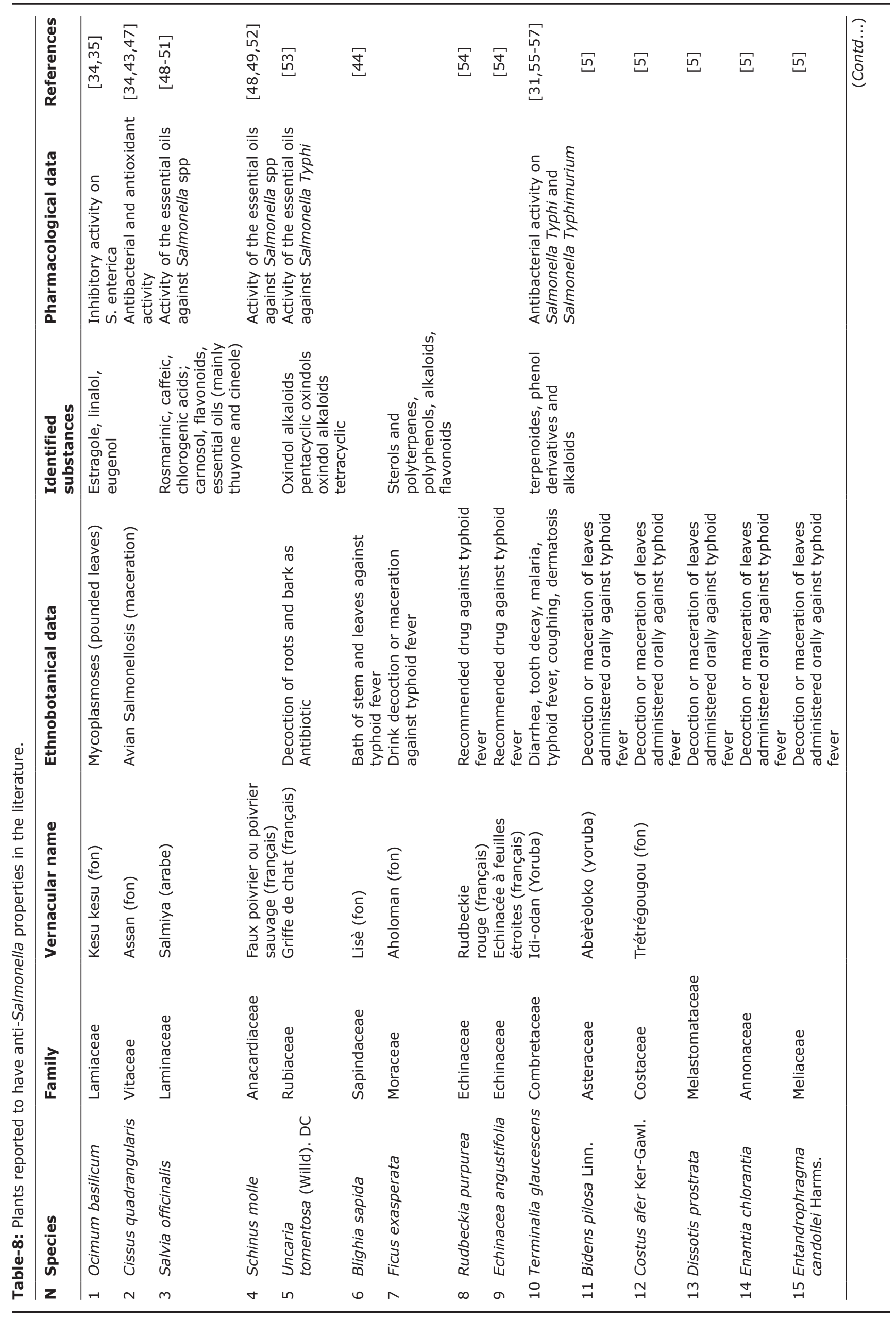




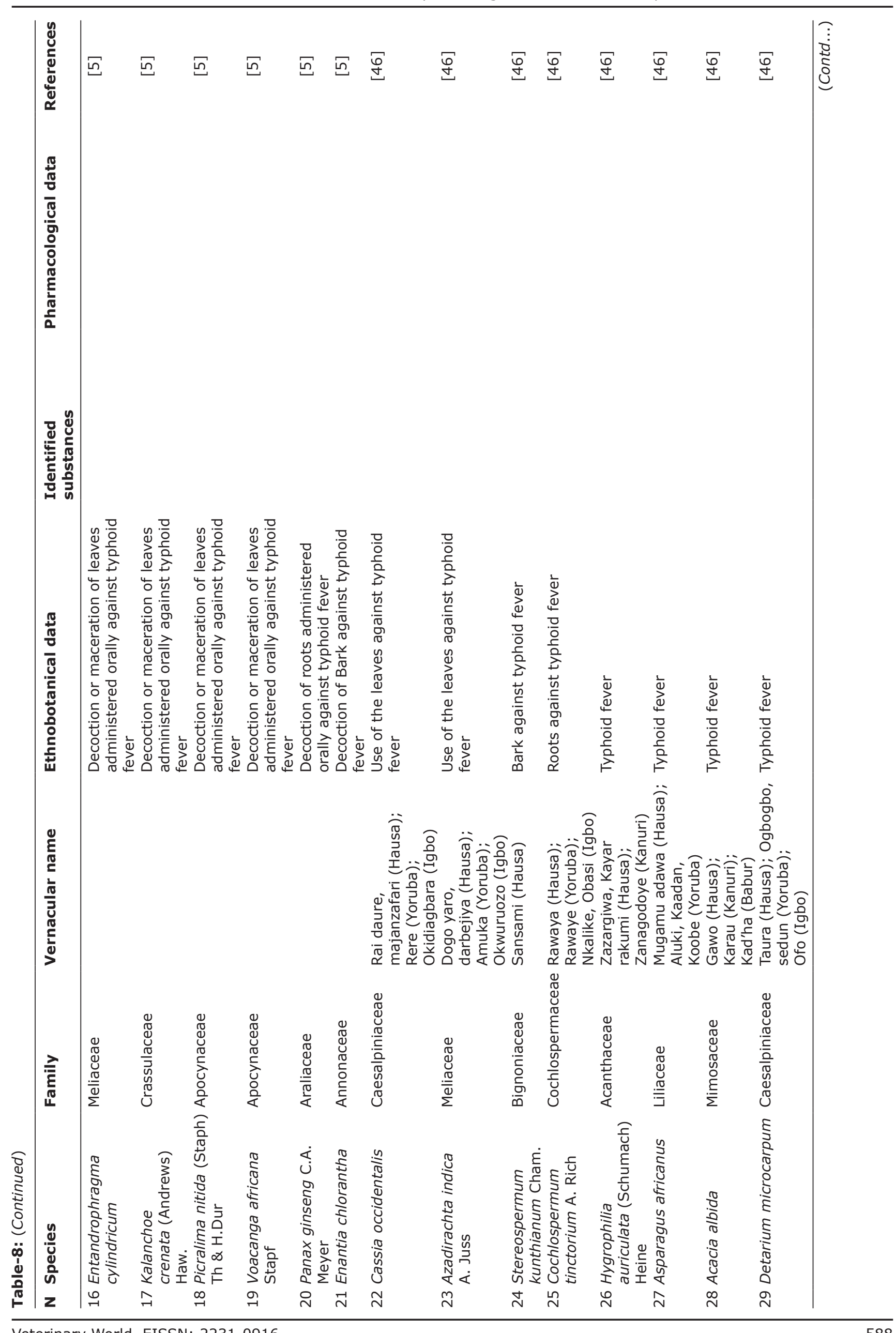




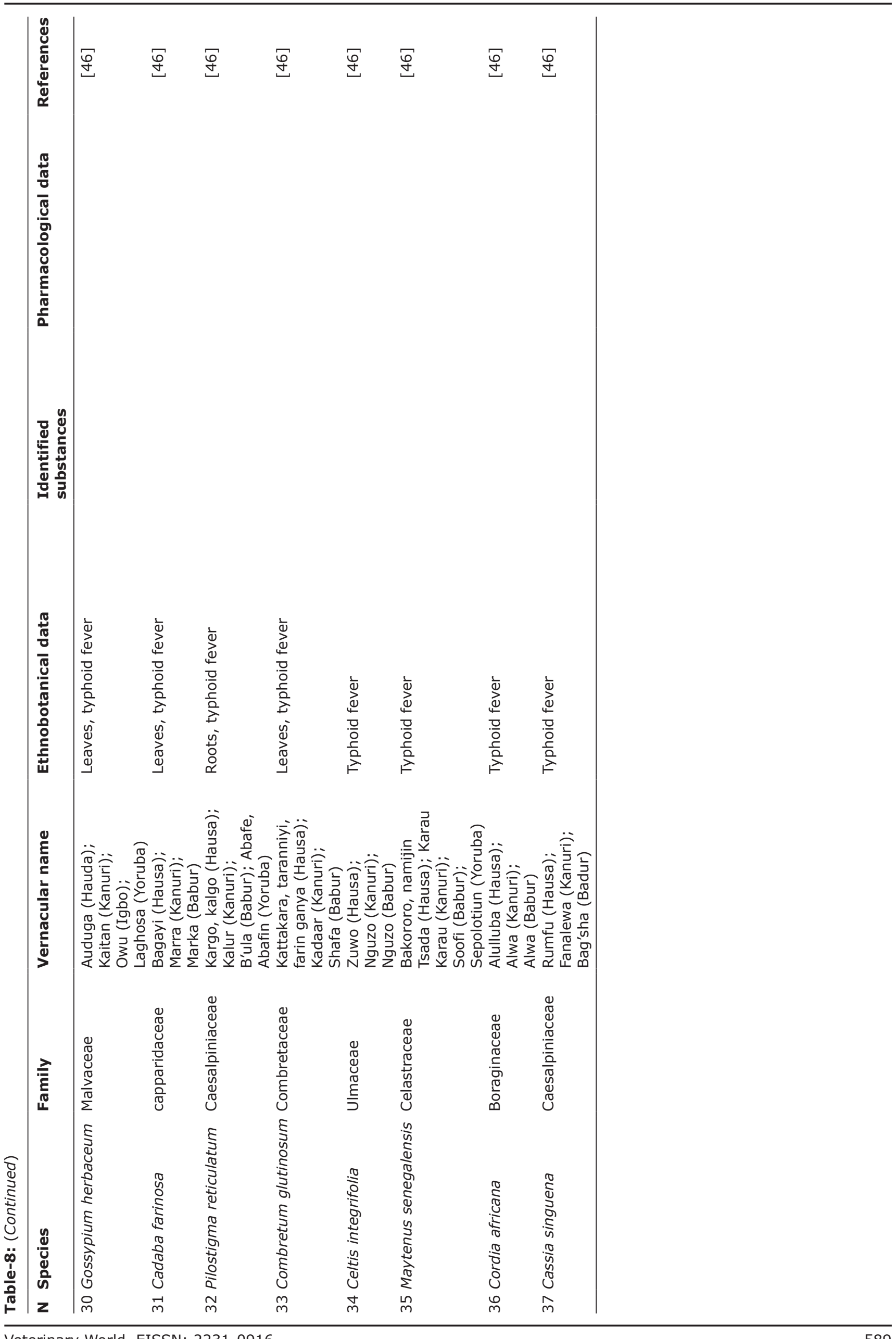


and flavonoids. These results show the enormous potentiality of the leaves of $M$. oleifera. The subsequent research of antibacterial properties of this plant against salmonelloses could be an alternative regarding issues of multidrug resistance.

The literature review revealed a number of plants that were not recorded in this study but known to have interesting anti-Salmonella properties. Ocimum basilicum for instance possesses an inhibitory activity on Salmonella Enterica [35]. This activity was confirmed by the chemical identification of pharmacological molecules such as estragole, linalool, and eugenol in that plant. Other studies reported the activity of the essential oils of Salvia officinalis and Schinus molle on Salmonella strains [48,49]. Keplinger et al. [53] described an anti-S. Typhi activity of Uncaria tomentosa. These properties are justified by the presence of pentacyclic and tetracyclics oxindole alkaloids in the organs of this plant. Many other plants were enumerated by different studies but without thorough pharmacological confirmations. All these data come to enrich the current database of Beninese plants that can be used in the treatment of salmonelloses.

Knowing that many people in Africa resort to herbal medicines as their first line of treatment when they are sick [74], the valorization of the recorded plant species through phytochemical and pharmacological studies could contribute to establishing evidence-based information on medicinal plants from African flora in general and Beninese in particular. It could be a contribution to the discovery of new molecules well controlled in terms of dosage to overcome challenges related to MDR Salmonella species that are hard to treat.

\section{Conclusion}

This study conducted in Southern Benin confirms that veterinary pharmacopeia is still least practiced among animal producers especially those dealing with monogastrics such as poultry and pigs. On the other hand, traditional healers use a number of medicinal plants in the treatment of typhoid fever. The association of herbal medicine and modern medicine can lead to an effective control of salmonelloses in animals and human. It therefore urges, to envisage experimental studies to validate the effectiveness of the recipes obtained from this study for future use. At this point, it is important to restore a mutual confidence between traditional healers and scientists to organize them for the betterment of ancestral knowledge that they have in herbal medicine. This will be very helpful to circumvent cost-related challenges of antibiotics and the MDR occurrences leading to treatment failures in developing countries and the world as a whole.

\section{Authors' Contributions}

TVD, YMGH, JA, TJD, FG, MB, HSB and LB have designed the concept and supervised the plan of work. They have also prepared the questionnaires and have prepared the manuscript. ED, BL, AA, HK, KF, AAniambossou, PA, EH, MS, FA and LF helped in collecting data and provided technical support. TVD, YMGH, ED, LB and JA analyzed and interpreted the data. All authors read and approved the final manuscript.

\section{Acknowledgments}

The authors are very grateful to the World Academy of Sciences for the Advancement of Science in Developing Countries (TWAS) and the United Nations Educational, Scientific and Cultural Organization (UNESCO). These two institutions have made this research possible through research funding allocated to the research team under the number 487 RG/BIO/AF/AC_G-FR3240293303.

\section{Competing Interests}

The authors declare that they have no competing interests.

\section{References}

1. Boko, M., Dougnon, T.V., Bankolé, H.S., Dougnon, T.J., Ahouangninou, C., Cledjo, P. and Soumanou, M. (2015) Pratiques d'élevage avicole au Sud-Bénin (Afrique de l'Ouest) et impacts sur l'hygiène des fumiers produits. Int. J. Biol. Chem. Sci., 9(6): 2740-2753.

2. WHO. (2003) Traditional Medicine. World Health Organization Fact Sheet No. 134, May, 2003. Available from: http://www.who.int/mediacentre/factsheets/2003/ fs134/en. Accessed on 11-08-2010.

3. Scallan, E., Griffin, P.M., Angulo, F.J., Tauxe, R.V. and Hoekstra, R.M. (2011) Foodborne illness acquired in the United States-unspecified agents. Emerg. Infect. Dis., 17(1): 7-15.

4. Bender, J., Hedberg, C., Boxrud, D., Besser, J., Wicklund, J., Smith, K. and Osterholm, M. (2001) Use of molecular subtyping in surveillance for Salmonella enteric serotype Typhimurium. N. Engl. J. Med., 344: 189-195.

5. Dibong, S.D., Mpondo, E.M., Ngoye, A., Kwin, M.F. and Betti, J.L (2011) Ethnobotanique et phytomédecine des plantes médicinales de Douala. J. Appl. Biosci., 37: 2496-2507.

6. Santos, R.L., Zhang, S., Tsolis, R.M., Kingsley, R., Adams, G.L. and Baumler, A. (2001) Animal models of Salmonella infections: Enteritis versus typhoid fever. Microbes Infect., 3(14): 1335-1344.

7. Ochiai, R.L., Acosta, C.J., Danovaro-Holliday, M.C., Baiqing, D., Bhattacharya, S.K., Agtini, M.D., Bhutta, Z.A., Canh, D.G., Ali, M., Shin, S., Wain, J., Page, A.L., Albert, M.J., Farrar, J., Abu-Elyazeed, R., Pang, T., Galindo, C.M., von Seidlin, L. and Clemens, J.D. (2008) Domi typhoid study group. A study of typhoid fever in five Asian countries: Disease burden and implications for controls. Bull. World Health Organ., 86: 260-268.

8. Ashbolt, N.J. (2004) Microbial contamination of drinking water and disease outcomes in developing regions. $J$. Toxicol., 198(1-3): 229-238.

9. Bhutta, Z.A. and Dewraj, H.L. (2006) Current concepts in the diagnosis and treatment of typhoid fever. $B M J$., 333(7558): 78-82.

10. Crump, J.A., Luby, S.P. and Mintz, E.D. (2004) The global burden of typhoid fever. Bull. World Health Organ., 82: 346-353.

11. Sinha, A., Sazawal, S., Kumar, R., Sood, S., Reddaiah, V.P. and Singh, B. (1999) Typhoid fever in children aged less than 5 years. Lancet, 354: 734-737.

12. Siddiqui, F.J., Rabbani, F., Hasan, R., Nizami, S.Q. and 
Bhutta, Z.A. (2006) Typhoid fever in children: Some epidemiological considerations. Int. J. Infect. Dis., 10: 215-222.

13. Rowe, B., Ward, L.R. and Threlfall, E.J. (1997) Multidrugresistant Salmonella Typhi: A worldwide epidemic. Clin. Infect. Dis., 24 Suppl 1: 106-109.

14. Renuka, K., Sood, S., Das, B.K. and Kapil, A. (2015) Highlevel ciprofloxacin resistance in Salmonella Enterica serotype typhi in India. J. Med. Microbiol., 54: 999-1000.

15. Bhutta, Z.A. (2006) Typhoid fever. In: Rakel, R.E., Bope, E.T., editors. Conn's Current Therapy. Saunders, Philadelphia, PA. p215-218.

16. Mweu, E. and English, M. (2008) Typhoid fever in children in Africa. Trop. Med. Int. Health, 13(4): 532-540.

17. Mert, A., Tabak, F., Ozaras, R., Aki, H. and Aktuglu, Y. (2004) Typhoid fever as a rare cause of hepatic, splenic and bone marrow granulomas. Intern. Med., 43(5): 436.

18. Acharya, G., Butler, T., Ho, M., Sharma, P.R., Tiwari, M., Adinkari, R.K., Khagda, J.B., Pokhrel, B. and Pathak, U.N. (1995) Treatment of typhoid fever: Randomized trial of a three-day course of ceftriaxone versus a fourteen-day course of chloramphenicol. Am. J. Trop. Med. Hyg., 52: 162-165.

19. Mirza, S.H., Beeching, N.J. and Hart, C.A. (1996) Multidrug resistant typhoid fever: A global problem. J. Med. Microbiol., 44: 317-319.

20. Wallace, M.R., Yousif, A.A., Mahroos, G.A., Mapes, T., Threlfall, E.J., Rowe, B. and Hyams, K.C. (1993) Ciprofloxacin verses ceftriaxone in the treatment of multiresistant typhoid fever. Eur. J. Clin. Microbiol. Infect. Dis., 12(12): 907-910.

21. Wain, J., Hoa, N.T.T., Chinh, N.T., Vinh, H., Everett, M.J., Diep, T.S., Day, N.P.J., Solomon, T., White, N.J., Piddock, L.J.V. and Parry, C.M. (1997) Quinolone-resistant Salmonella Typhi in Vietnam: Molecular basis of resistance and clinical response to treatment. Clin. Infect. Dis., 25: 1404-1410.

22. Vinh, H., Wain, J., Vo, T.N., Cao, N.N., Mai, T.C., Bethel, D., Nguyen, T.T., Tu, S.D., Nguyen, M.D. and White, N.J. (1996) Two or three days of ofloxacin treatment for uncomplicated multidrug-resistant typhoid fever in children. Antimicrob. Agents Chemother., 40: 958-961.

23. Butler, T. and Girard, E. (1993) Comparative efficacies of azithromycin and ciprofloxacin against experimental Salmonella Typhimurium infection in mice. J. Antimicrob. Chemother., 31(2): 313-319.

24. Gijtenbeek, J.M.M., van den Bent, M.J. and Vecht, C.J. (1999) Cyclosporin neurotoxicity. J. Neurotox., 246: 339-346.

25. Abbiw, D., Gillett, H., Agbovie, T., Akuetteh, B., Amponsah, K. and Afriyie, O. (2002) Conservation and Sustainable Use of Medicinal Plants in Ghana. United Nations Environment Programme, Cambridge, p3-32.

26. Omobuwajo, O.R., Alade, G.O. and Sowemimo, A. (2008) Indigenous knowledge and practices of women herb sellers of south-western Nigeria. Indian J. Tradit. Knowl., 7: 505.

27. Akoègninou, A., van der Burg, W.J. and van der Maesen, L.J.G. (2006) Flore Analytique du Bénin Bénin. Backhuys Publishers, Leiden, p1043.

28. Igue, A.M., Saïdou, A., Adjanohoun, A., Ezui, G., Attiogbe, P., Kpagbin, G., Gotoechan-Hodonou, H., Youl, S., Pare, T., Balogoun, I., Ouedraogo, J., Dossa, E., Mando, A. and et Sogbedji, J.M. (2013) Evaluation de la fertilité des sols au sud et centre du Bénin. Bull. Rech. Agronom. Bén., 1: 12-23.

29. Adomou, A.C., Agbani, O.P. and Sinsin, B. (2011) Plantes. In: Neuenschwander, P., Sinsin, B., Goergen, G., editors. Protection de la Nature en Afrique de l'Ouest: Une Liste Rouge Pour le Bénin. Nature Conservation in West Africa: Red List for Benin. International Institute of Tropical Agriculture, Ibadan, Nigeria. p21-46.

30. Klotoé, J.R., Dougnon, T.V., Koudouvo, K., Atègbo, J.M., Loko, F., Akoègninou, A., Aklikokou, K., Dramane, K. and Gbeassor, M. (2013) Ethnopharmacological survey on antihemorrhagic medicinal plants in South of Benin. Eur. J.
Med. Plants, 3(1): 40-51.

31. Adjanohoun, E., Adjaktdjè, V., Ahyi, M.R.A., Aké Assi, L., Akoègninou, A., d'Almeida, J., Apovo, F., Boukef, K., Chadare, M., Cusset, G., Dramane, K., Eymé, J., Gassita, J.N., Gbaguidi, N., Goudoté, E., Guinko, S., Houngnon, P.L.I., Saadou, M., Sodogandji, T.H., de Souza, S., Tchabi, A., Dossa, C.Z. and Zohoun, T.H. (1989) Contribution Aux Etudes Ethnobotaniques et Floristiques au Bénin. ACCT, Paris, p895.

32. de Souza, S. (1988) Flore du Bénin: Noms des Plantes Dans Les Langues Nationales Béninoises. Imprimerie NotreDame, Cotonou.

33. Millogo-Koné, H., Kini, B.F., Yougbaré, Z., Yaro, M.B. and Sawadogo, M. (2012) Etudes de la phytochimie et de l'activité antimicrobienne in vitro des feuilles de Moringa oleifera (Moringaceae). Rev. Cames Ser. Pharm. Med. Tradit. Afr., (16): 1-16.

34. Dassou, G.H., Adomou, A.C., Yédomonhan, H., Ogni, A.C., Tossou, G.M., Dougnon, J.T. and et Akoègninou, A. (2015) Flore médicinale utilisée dans le traitement des maladies et symptômes animaux au Bénin. J. Anim. Plant Sci., 26(1): 4036-4057.

35. Kpodekon, M.T., Boko, K.C., Mainil, J.G., Farougou, S., Sessou, P., Yehouenou, B., Gbenou, J., Duprez, J.N. and Bardiau, M. (2013) Composition chimique et test d'efficacité in vitro des huiles essentielles extraites de feuilles fraîches du basilic commun (Ocimum basilicum) et du basilic tropical (Ocimum gratissimum) sur Salmonella Enterica sérotypes Oakland et Legon. J. Soc. Ouest-Afr. Chim., 35: 41-48.

36. Hounzangbé-Adoté, S.M., Attakpa, E.Y., Zinsou, E., Hounkpe, V. and et Hoste, H. (2008) Effets antiparasitaires de la graine de papaye sur les strongles gastro-intestinaux de petits ruminants au Sud-Bénin. Bull. Rech. Agron. Benin, 60: 13-18.

37. Onzo, C.F., Azokpota, P., Dah-Nouvlessounon, D., Toure, H., Adjatin, A. and Baba-Moussa, L. (2015) Évaluation de l'activité antimicrobienne de quatre feuilles utilisées comme emballages dans l'artisanat agroalimentaire au Bénin. J. Appl. Biosci., 95: 9015-9027.

38. Okigbo, R.N. and Omodamiro, O.D. (2006) Antimicrobial effect of leaf extract of pigeon pea (Cajanus cajan (L) Mill sp) on some human pathogen. J. Herb. Spices Med. Plants, 12(1-2): 117-127.

39. Agbankpe, A., Dougnon, T.V., Bankole, S.H., Houngbegnon, O., Dah-Nouvlessounon, D. and BabaMoussa, L. (2016) In vitro antibacterial effects of Crateva adansonii, Vernonia amygdalina and Sesamum radiatum used for the treatment of infectious diarrhoeas in Benin. J. Infect. Dis. Ther., 4: 281.

40. Fadimu, O.Y., Iliya, M. and Sani, R.Z. (2014) Ethnomedicinal survey of anti-typhoid plants in ijebu ode local government area of Ogun state, Nigeria. Int. J. Sci. Nat., 5(2): 332-336.

41. Agbankpè, A.J., Dougnon, T.V., Bankolé, H.S., Yèhouénou, B., Yédomonhan, H., Lègonou, M., Dougnon, T.J. (2014) Etude ethnobotanique des légumes feuilles thérapeutiques utilisés dans le traitement des diarrhées au Sud - Bénin (Afrique de l'Ouest). Int. J. Biol. Chem. Sci., 8(4): 1784-1795.

42. Yèhouénou, B., Noudogbessi, J.P., Sessou, P., Avlessi, F. and Sohounhloué, D. (2010) Etude chimique et activités antimicrobiennes d'extraits volatils des feuilles et fruits de Xylopia aethiopica (DUNAL) A. Richard contre les pathogènes des denrées alimentaires. J. Soc. Ouest. Afr. Chim., 29: 19-27.

43. Ogni, C.A., Kpodékon, T.M., Dougnon, T.J., Dassou, H., Goussanou, J.S.E., Boko, C., Koutinhouin, G.B., Youssao, K.I. and Akoegninou, A. (2016) Dominant bacterial diseases in the extensive and semi-intensive animal breeding and their treatment method by ethno veterinary medicine in Benin. J. App. Pharm. Sci., 6(4): 150-158.

44. Adomou, A.C., Yedomonhan, H., Djossa, B., Legba, S.I., 
Oumorou, M. and Akoegninou, A. (2012) Etude Ethnobotanique des plantes médicinales vendues dans le marché D'abomey-Calavi au Bénin. Int. J. Biol. Chem. Sci., 6(2): 745-772.

45. Lega, I. (2010) Evaluation des Propriétés Antibactériennes, in vitro D'extraits de Feuilles d'Argemone mexicana L. (Papaveraceae). Thèse Pour L'obtention du Diplôme de Doctorat en Pharmacie (Diplôme d'Etat). Université de Ouaga de Ouagadougou.

46. Sodipo, O.A. and Wannang, N.N. (2015) Ethnopharmacological survey of plants used by trado-medical practitioners (Tmps) in the treatment of typhoid fever in gomari airport ward, jere local government area, Borno state, Nigeria. Am. J. Ethnomed., 2(4): 185-218.

47. Murthy, K.N.C., Vanitha, A., Swamy, M.M. and Ravishankar, G.A (2013) Antioxidant and antimicrobial activity of Cissus quadrangularis L. J. Med. Food, 6(2): 99-105.

48. Hayouni, E.A., Chraief, I., Abedrabba, M., Bouix, M., Leveau, J.Y., Mohammed, H. and Hamdi, M. (2008) Tunisian Salvia officinalis L. and Schinus molle L. Essential oils: Their chemical compositions and their preservative effects against Salmonella inoculated in minced beef meat. Int. J. Food Microbiol., 125: 242-251.

49. Valverde, M.T., Iniesta, F.M., Garrido, L.C., Rodríguez, A.T., García-García, I., Macanas, H. and Roda, R.C. (2012). Inactivation of Salmonella spp. in refrigerated liquid egg products using essential oils and their active compounds. In: Proceedings in International Conference on Food Innovation - Food in Nova, University dad Politecnica de Valencia.

50. Newall, C.A., Anderson, L.A. and Phillipson, J.D. (1996) Herbal medicines. A Guide for Health-Care Professionals. Royal Pharmaceutical Society of Great Britain, London. p296.

51. Bouaziz, M., Yangui, T., Sayadi, S. and Dhouib, A. (2009) Disinfectant properties of essential oils from Salvia officinalis L. cultivated in Tunisia. Food Chem. Toxicol., 47: 2755-2760.

52. Bajpai, V.K., Baek, K.H. and Kang, S.C. (2011) Control of Salmonella in foods by using essential oils: A review. Food Res. Int. DOI: 10.1016/j.foodres.2011.04.052.

53. Keplinger, K., Laus, G., Wurm, M., Dierich, M.P. and Teppner, H. (1999) Uncaria tomentosa (Willd). DC.Utilisation de l'Ethnomédicine et nouveau résultat pharmacologique, toxicologique et botanique. J. Ethnopharmacol., 64: 23-34.

54. Steinmetz, E.F. (1954) Matéria Medica Vegetabilis. Janvier, Amderdame. p523-524.

55. Bolou, G.E., Attioua, B., N'guessan, A.C., Coulibaly, A., N'guessan, J.D. and Djaman, A.J. (2011) Évaluation in vitro de l'activité antibactérienne des extraits de Terminalia glaucescens planch sur Salmonella Typhi et Salmonella typhimurium. Bull. Soc. R. Sci. Liège, 80: 772-790.

56. Rotimi, V.O., Laughon, B.E., Bartlett, J.G. and Mosadomi, H.A. (1988) Activities of Nigerian chewing stick extract against Bacteroides gingivalis and Bacteroides melaninogenicus. Antimicrob. Agents Chemother, 32: 598-600.

57. Ojo, O.O., Nadro, M.S. and Tella, I.O. (2006) Protection of rats by extracts of some common Nigerian trees against acetaminophen-induced hepatotoxicity. Afr. J. Biotechnil., 5(9): 755-760.

58. Dassou, G.H. (2013) Étude Ethnobotanique des Plantes à Usages Vétérinaires au Bénin: Cas des communes de Bohicon, Abomey, et Dassa-Zoumè. Mémoire de Master, Université d'Abomey-Calavi, Faculté des Sciences et Techniques. p64.
59. Fah, L., Klotoé, J.R., Dougnon, V., Koudokpon, H., Fanou, V.B., Dandjesso, C. and Loko, F. (2013) Étude ethnobotanique des plantes utilisées dans le traitement du diabète chez les femmes enceintes à Cotonou et AbomeyCalavi (Bénin). J. Anim. Plant Sci.,18(1): 2647-2658.

60. Dassou, G.H., Ogni, C.A., Yédomonhan, H., Adomou, A.C., Tossou, M., Dougnon, J.T. and et Akoègninou, A. (2014) Diversité ethnobotanique et vulnérabilité des plantes à usages vétérinaires au Nord-Bénin. Int. J. Biol. Chem. Sci., 1(8): 189-210.

61. Sacramento, TI. (2008) Etude de l'effet antiparasitaire des graines de papaye (Carica papaya) chez l'aulacode d'élevage: cas des aulacodiculteurs au Sud du Bénin. Mémoire de DEA, FSA/UAC. 63p.

62. Ogni, C.A., Kpodékon, M.T., Dassou, H.G., Boko, C.K., Koutinhouin, B.G., Dougnon, J.T., Youssao, A.K.I., Yedomonhan, H. and Akoegninou, A. (2014) Ethnopharmacological inventory of plants used in the treatment of the parasitic pathologies in the extensive and semi-intensive breeding's of Benin. Int. J. Biol. Chem. Sci., 8: 1089-1110.

63. Grunwald, J. (1995) The European phytomedicine market: Figures, trends, analysis. Herbgram, 38: 60-65.

64. Crag, G.M., Schepartz, S.A., Suffness, M. and Grever, M.R. (1993) The taxol supply crisis: New NCI policies for handling the large-scale production of novel natural product anticancer and anti-HIV agents. J. Nat. Prod., 56: 1657-1668.

65. Craig, W.J. (1999) Health-promoting properties of common herbs. Am. J. Clin. Nutr., 70(3): 491-499.

66. Kermanshai, R., McCarry, B.E., Rosenfeld, J., Summers, P.S., Weretilnyk, E.A. and Sorger, G.J. (2001). Benzyl isothiocyanate is the chief or sole anthelminthic in papaya seed extracts. Phytochemistry, 57: 427-435.

67. Hounzangbé-Adoté, M.S., Mensah, G.A., Hounkpè, B. and Moutairou, K. (2004) Possibilité de Circulation Parasitaire Entre Aulacodes et Petits Ruminants. In: Acte de L'atelier Scientifique 4 du 14 au 17, December, 2004.

68. Brunette, S. and Hoste, H. (2006) Les monomères des tanins condensés affectent le dégainement des larves des nématodes parasites des ruminants. J. Agric. Food Chem., 54: 7481-7487.

69. Koffuor, G.A., Abruquah, A.A., Audu, R., Amoah, J. and Agwah, D. (2016) Patronage and perceived efficacy of herbal antityphoid preparations, and anti-Salmonella activity of a herbal preparation used in Ghana. J. Appl. Pharm. Sci., 6(3): 1-7.

70. Ebong, P.E., Atangwho, I.J., Eyong, E.U. and Egbung, G.E. (2008) The antidiabetic efficacy of combined extracts from two continental plants: Azadirachta indica (A. Juss) (Neem) and Vernonia amygdalina (Del.) (African bitter Leaf). Am. J. Biochem. Biotechnol., 4(3): 239-244.

71. Abosi, A.O., Raseroka, B.H. and Benjamin, H. (2003) In vivo antimalarial activity of Vernonia amygdalina. Br. J. Biomed. Sci., 60(2): 89-91.

72. Akah, P.A. and Okafor, C.L. (1992) Blood sugar lowering effect of Vernonia amygdalina Del, in an experimental rabbit model. Phytother. Res., 6(3): 171-173.

73. Kone, D. (2009) Enquête Ethnobotanique de Six Plantes Médicinales Maliennes - Extraction, Identification D'alcaloïdes - Caractérisation, Quantification de Polyphénols: Etude de Leur Activité Antioxydante. Mémoire de Thèse. Thèse en Cotutelle, Université PAUL VERLAINE DE METZ - UPV - M (France)-Université de Bamako, Mention Chimie Organique.

74. Gyasi, R.M., Siaw, L.P. and Mensah, C.H. (2015) Prevalence and pattern of traditional medical therapy utilization in Kumasi metropolis and Sekyere South district, Ghana. $J$. Ethnopharmacol., 161: 138-146. 